\title{
Intestinal Helminthiasis and Anaemia in Youngsters from Matriz da Luz, District of São Lourenço da Mata, State of Pernambuco, Brazil
}

\author{
Maria Rejane Ferreira ${ }^{+}$, Wayner Souza, Emília P Perez, Tiago Lapa, Alexandre \\ B Carvalho, André Furtado, Hélio B Coutinho, Derek Wakelin*
}

\author{
Centro de Pesquisas Aggeu Magalhães-Fiocruz, Campus da UFPE, Caixa Postal 7472, 50670-420 Recife, PE, \\ Brasil *Dept. of Life Science, University of Nottingham, NG7 2RD, UK
}

A group of youngsters (4-18 years old) in northeast Brazil was studied to establish the prevalence of anaemia and intestinal parasitism, as well as to analyze the correlation between them. Two criteria were used to determine the state of anaemia, the level of haemoglobin and the mean of corpuscular volume. The first was considered a single criterion and the second an associated criteria, used in an attempt to correlate anaemia with iron deficiency. The prevalence of intestinal parasitism was 93\%, while the prevalence of anaemia was $43.1 \%$ and $16.1 \%$ according to the criteria employed (single or associated respectively). Anaemia was significantly associated with both sex and age. No significant statistical difference was observed when the association was made between each parasite and anaemia even with those more related to anaemia.

Key words: anaemia - helminths - intestinal parasites - iron deficiency - haemoglobin

Anaemia and iron deficiency are worldwide serious public health problems, with very high prevalence rates in children and pregnant women (OMS 1972, Oliveira 1990, Unicef 1994b).

Besides disrupting growth, iron deficiency increases susceptibility to infections, enhances the development of infectious processes, interferes in mental activity leading to apathy, irritability and lower powers of concentration as well as a reduced learning capacity, chiefly in childhood (Vyas \& Chandra 1984, Bundy 1985, Arruda \& Arruda 1994). More than two billion people, corresponding to more than $1 / 3$ of the human population in the world, are anaemic (Simmons 1985, PAHO \& WHO 1994, Cook et al. 1994). It is known that between $30 \%$ to $60 \%$ of persons aged less than 15 in Africa suffer from iron deficiency anaemia. Higher percentages were detected in children aged up to 7 years. In Asia, anaemia occurs in $50 \%$ of children reaching $92 \%$ in those aged less than 2 years, while in South America prevalence oscillates between 15\% to 50\% (Pritchard et al. 1991).

This work was supported by European Union (DG XII), Conselho Nacional de Desenvolvimento Científico e Tecnológico (CNPq) and Fundação de Amparo à Ciência e Tecnologia de Pernambuco (FACEPE).

${ }^{+}$Corresponding author. Fax: +55-81-453.3046

Received 11 September 1997

Accepted 18 February 1998
Several studies have identified the main causes of anaemia iron deficiency as inadequate iron ingestion and abnormal loss of blood as a consequence of parasitic infection (Sigulem et al. 1978, Salzano et al. 1985, Szarfarc 1985, Robertson et al. 1992, Turconi \& Turconi 1992).

In Brazil, anaemia has been studied for the last three decades, however, many of these studies were carried out on selected samples of particular groups (demand of the health services, school children, etc.), making it impossible to establish an epidemiological profile of anaemia that would be relevant to the whole country. Nevertheless those studies have suggested that anaemia, chiefly those caused by the iron deficiency, are frequent in children (Salzano et al. 1980, Szarfarc 1985, Monteiro \& Szarfarc 1987, Romani et al. 1991, Torres et al. 1994) and pregnant women (Salzano et al. 1980, Arruda et al. 1991).

On the other hand, in the same populations of poverty people, the prevalence of intestinal helminths is very high. Recent estimates (cited by Chan 1997) are of 3,452 billion of people that harbours Ascaris lumbricoides (1,273 million), hookworm (1,277 million) and Trichuris trichiura (902 million). Intestinal helminth infection only in rare situations causes serious disease, as intestinal obstruction in ascariasis or trichuriasis dysentery. The main symptoms are nonspecific like reduced growth, physical fitness and cognitive abilities, which are similar to those of moderate anaemia, the responsibilization of intestinal helminths as the 
cause of anaemia by practioners is very frequent (Unicef 1994a).

In the present study, the prevalences of anaemia and intestinal helminthiasis have been determined in a high risk population and the possibility of existing correlation between them was established.

\section{MATERIALS AND METHODS}

This study was carried out in the locality of Matriz da Luz, a district of São Lourenço da Mata, Recife, State of Pernambuco, Brazil. Part of the area was formerly covered by the characteristic vegetation of a tropical forest, that has been destroyed and substituted by the monoculture of sugar-cane plantations (Barbosa \& Silva 1992).

More than $50 \%$ of São Lourenço da Mata population, 10,743 inhabitants, is between 5 and 19 years of age (FIBGE 1991). Matriz da Luz is an agricultural area, presenting urban-rural characteristics. The climate is hot and humid and the average annual temperature is $28^{\circ} \mathrm{C}$. Our sample consisted of 299 children: 153 (51.2\%) male and 146 $(48.8 \%)$ female. The commitment of the municipal school-teachers and their contact with the families encouraged involvement in the project. After the agreement of their parents, children were registered and invited to go to the local health unit. They were examined by physicians and two samples of faeces and one of blood were collected. Stool examinations were made according to Lutz' method, described in Rey (1991), with a modification that consisted of making a smear of $50 \mathrm{ml}$ of sediment for microscope examination. Eggs and larvae of each parasite were counted and the total number of eggs or larvae/gram of faeces was calculated. A child was considered positive if at least one egg or larva was found in one of the exams. The haematological study was done by using a haematological analyzer (CELL-DYN 3000CS).

A child was considered anaemic when the hae- moglobin level was lower than the WHO criterion, (children aged less than 6 whose haemoglobin level is lower than $11 \mathrm{~g} / \mathrm{dl}$; children aged between 6-14 whose haemoglobin level is lower than $12 \mathrm{~g} / \mathrm{dl}$ and males aged more than 14 whose haemoglobin level is lower than $13 \mathrm{~g} / \mathrm{dl}$ ); this was considered the single criterion. We also considered in our definition of anaemia the associated criterion of microcytosis identified when corpuscular medium volume (CMV) was lower than 80fl (Rapaport 1990, Desai $\&$ Choudrhy 1993). Both criteria were used in order to obtain a better approximation of the number of anaemics who presented iron deficiency, since a level of haemoglobin between 9-12g/dl and a concomitant microcytosis indicate an iron deficiency, mild thalassaemia or chronic infection (Rapaport 1990, Desai \& Choudrhy 1993).

Correlations were analyzed between the prevalence of anaemia and sex and age as well as parasite prevalence and intensity. Statistical analysis were carried out using the EPIINFO 5.01 version (Dean et al. 1990). Prevalence ratios and Chisquare tests were also employed, using 0.05 as the critic level of significance.

\section{RESULTS}

When the single criterion was used, the recorded prevalence of anaemia was $43.1 \%, 52.1 \%$ in males and $34.6 \%$ in females (Table I).

The frequency distribution of haemoglobin levels by sex and age showed for males aged $4-5$ years mean values higher than the adopted critical value. The same was observed in females aged 14 or more (Table III).

Analyses of the association between prevalence of anaemia and age also showed statistical significance $\left(c^{2}=38.28, p<0.01\right)$. Statistical significance was also observed when anaemia was associated with both age and sex $\left(\mathrm{c}^{2}=24.83, \mathrm{p}<0.01\right)$ for males and $\left(c^{2}=14.33, \mathrm{p}<0.01\right)$ for females. Asso-

TABLE I

Anaemia prevalence according to sex and age - Matriz da Luz, PE, Brazil

\begin{tabular}{|c|c|c|c|c|c|c|c|c|c|c|c|c|c|c|}
\hline \multirow{4}{*}{$\begin{array}{l}\text { Age } \\
\text { (years) }\end{array}$} & \multicolumn{12}{|c|}{ Sex } & \multirow{3}{*}{\multicolumn{2}{|c|}{$\begin{array}{l}\text { Total } \\
\text { (group) }\end{array}$}} \\
\hline & \multicolumn{6}{|c|}{ Male } & \multicolumn{6}{|c|}{ Female } & & \\
\hline & \multicolumn{2}{|c|}{ Total } & \multicolumn{2}{|c|}{ Single } & \multicolumn{2}{|c|}{ Associated } & \multicolumn{2}{|c|}{ Total } & \multicolumn{2}{|c|}{ Single } & \multicolumn{2}{|c|}{ Associated } & & \\
\hline & No. & $\%$ & No. & $\%$ & No. & $\%$ & No. & $\%$ & No. & $\%$ & No. & $\%$ & No. & $\%$ \\
\hline $4-5$ & 18 & 52.9 & 4 & 25 & 2 & 12.5 & 16 & 47.1 & 3 & 16.7 & 2 & 11.1 & 34 & 11.4 \\
\hline $6-7$ & 29 & 50 & 22 & 75.9 & 6 & 20.7 & 29 & 50 & 19 & 65.5 & 6 & 20.7 & 58 & 19.4 \\
\hline $8-9$ & 25 & 41.7 & 21 & 60 & 7 & 20 & 35 & 58.3 & 13 & 52 & 6 & 24 & 60 & 20.1 \\
\hline $10-11$ & 31 & 51.7 & 14 & 48.3 & 3 & 10.3 & 29 & 48.3 & 8 & 25.8 & 7 & 22.6 & 60 & 20.1 \\
\hline $12-13$ & 22 & 55 & 7 & 38.9 & 1 & 5.6 & 18 & 45 & 6 & 27.3 & 3 & 13.6 & 40 & 13.4 \\
\hline 14 or + & 28 & 59.6 & 8 & 42.1 & 4 & 21.1 & 19 & 40.4 & 4 & 14.3 & 1 & 3.6 & 47 & 15.6 \\
\hline Total & 153 & 51.2 & 76 & 52.1 & 23 & 15.8 & 146 & 48.8 & 53 & 34.6 & 25 & 16.3 & 299 & 100 \\
\hline
\end{tabular}


ciation between prevalence of anaemia and sex stratified by age, showed statistical significance only for the group aged 14 or more $\left(\mathrm{c}^{2} \mathrm{M}-\mathrm{H}\right.$ summarized $=6.90, \mathrm{p}<0.01)($ Table III).

Using the associated criterion, the prevalence of anaemia was $15.8 \%$ for males and $16.3 \%$ for females. In addition no associations presenting statistical significance were recorded with prevalence of anaemia and age $\left(c^{2}=4.92, p>0.05\right)$ and anaemia and sex $\left(\mathrm{PR}=1.04 ; \mathrm{CI}=0.62-1.74 ; \mathrm{c}^{2} \mathrm{M}-\right.$ $\mathrm{H}=0.02, \mathrm{p}>0.05$ ) (Table I).

The overall prevalence of parasitism was $93 \%$. In males the frequency was $91.1 \%$, slightly lower than that registered for females $(94.8 \%)$. No statistically significant association was found between the prevalence of different parasites and sex ( $P R=0.96 ; C I=0.90-1.02 ; c^{2} \mathrm{M}-\mathrm{H}=1.54, \mathrm{p}>0.05$ ).

In the analyses of the distribution of the different parasites according to age, no associations were detected.

The utilization of both criteria to classify anaemia, did not identify any association of statistical significance when the values of eggs per gram (epg) of each parasite was related to anaemia (Table II), even with Ancylostomidae (Fig. 1) and T. trichiura (Fig. 2).

\section{DISCUSSION}

The prevalence of $43.1 \%$ of anaemia detected in Matriz da Luz, based on the single criterion constitutes a serious public health problem according to the International Nutritional Anaemia Consultative Group which recommends the adoption of collective measures of intervention in those populations that present similar rates (Vital 1993).

In the frequency distribution of haemoglobin patterns by sex and age (Table III) it was observed an increase of the intervals between the median values and the pattern measures where occurs the change of criteria, according to the age group. We detected high prevalences in the 6-7 year age group (75.9\% for males and $65.5 \%$ for females) (Table I). A higher prevalence of anaemia in males of 14 years or older may also occur as a consequence of the change of criterion (Table III).

High prevalences have also been registered in

TABLE II

Anaemia prevalence according to helmints infection and eggs per gram of faeces - Matriz da Luz, PE, Brazil

\begin{tabular}{|c|c|c|c|c|c|c|c|c|c|}
\hline \multicolumn{10}{|c|}{ Parasites } \\
\hline & \multicolumn{3}{|c|}{ Ascaris lumbricoides } & \multicolumn{3}{|c|}{ Ancylostomidae } & \multicolumn{3}{|c|}{ Trichuris trichiura } \\
\hline \multirow[t]{2}{*}{ Eggs/g/faeces } & \multicolumn{2}{|r|}{ Single $^{a}$} & \multirow{2}{*}{$\begin{array}{c}\text { Associated }^{b} \\
\%\end{array}$} & \multicolumn{2}{|r|}{ Single $^{a}$} & Associated $^{b}$ & \multicolumn{2}{|r|}{ Single $^{a}$} & \multirow{2}{*}{$\begin{array}{c}\text { Associated }^{b} \\
\%\end{array}$} \\
\hline & No. & $\%$ & & No. & $\%$ & $\%$ & No. & $\%$ & \\
\hline$<100$ & 37 & 40.5 & 16.2 & 58 & 43.1 & 12.1 & 47 & 40.4 & 14.9 \\
\hline $100-299$ & 33 & 45.5 & 18.2 & 54 & 42.6 & 14.8 & 59 & 49.2 & 15.3 \\
\hline $300-499$ & 15 & 53.3 & 20.0 & 34 & 47.1 & 20.6 & 32 & 59.4 & 28.1 \\
\hline $500-699$ & 11 & 81.8 & 18.2 & 19 & 36.8 & 15.8 & 13 & 38.5 & 15.4 \\
\hline $700-999$ & 13 & 46.2 & 7.7 & 17 & 58.8 & 29.4 & 18 & 27.8 & 11.1 \\
\hline \multirow[t]{2}{*}{1000 or +} & 76 & 39.5 & 14.5 & 43 & 41.9 & 11.6 & 36 & 44.4 & 13.9 \\
\hline & \multicolumn{3}{|c|}{$\begin{array}{l}\mathrm{c}^{2}=7.69 ; \mathrm{p}>0.05^{a} \\
\mathrm{c}^{2}=1.14 ; \mathrm{p}>0.05^{b}\end{array}$} & \multicolumn{3}{|c|}{$\begin{array}{l}c^{2}=2.18 ; \mathrm{p}>0.05^{a} \\
c^{2}=4.21 ; \mathrm{p}>0.05^{b}\end{array}$} & \multicolumn{3}{|c|}{$\begin{array}{l}c^{2}=5.85 ; p>0.05^{a} \\
c^{2}=3.85 ; p>0.05^{b}\end{array}$} \\
\hline
\end{tabular}

TABLE III

Prevalence of parasitism and haemoglobin mean values (95\% confidence interval), compared to WHO patterns, according to age and sex - Matriz da Luz, PE, Brazil

\begin{tabular}{ccccccc}
\hline $\begin{array}{c}\text { Age } \\
\text { (years) }\end{array}$ & Ancyl. & T. trich. & $\begin{array}{c}\text { A. lumb. } \\
\text { Mean } \pm \mathrm{sd}\end{array}$ & $\begin{array}{c}\mathrm{Hb}(\mathrm{g} / \mathrm{dl}) \\
\text { Male } \\
\text { Mean } \pm \mathrm{sd}\end{array}$ & $\begin{array}{c}\mathrm{Hb}(\mathrm{g} / \mathrm{dl}) \\
\text { Female } \\
\mathrm{Hb}(\mathrm{g} / \mathrm{dl})\end{array}$ & WHO \\
\hline $4-5$ & 70.6 & 61.8 & 55.9 & $11.1 \pm 1.172$ & $11.3 \pm 0.672$ & 11 \\
$6-7$ & 72.4 & 63.8 & 56.9 & $11.0 \pm 1.307$ & $11.4 \pm 0.990$ & 12 \\
$8-9$ & 78.3 & 81.7 & 75 & $11.4 \pm 1.049$ & $11.7 \pm 0.953$ & 12 \\
$10-11$ & 80 & 76.7 & 63.3 & $11.8 \pm 1.196$ & $12.0 \pm 0.794$ & 12 \\
$12-13$ & 72.5 & 67.5 & 62.5 & $11.9 \pm 1.049$ & $12.0 \pm 0.983$ & 12 \\
14 or + & 85.1 & 63.8 & 63.8 & $12.4 \pm 1.404$ & $12.5 \pm 0.953$ & 12 (female); 13 (male) \\
\hline
\end{tabular}

Ancyl.: Ancylostomidae; T. trich.: Trichuris trichiura; A. lumb.: Ascaris lumbricoides; Mean \pm sd: mean and standard deviation; WHO: World Health Organization, 1972. 

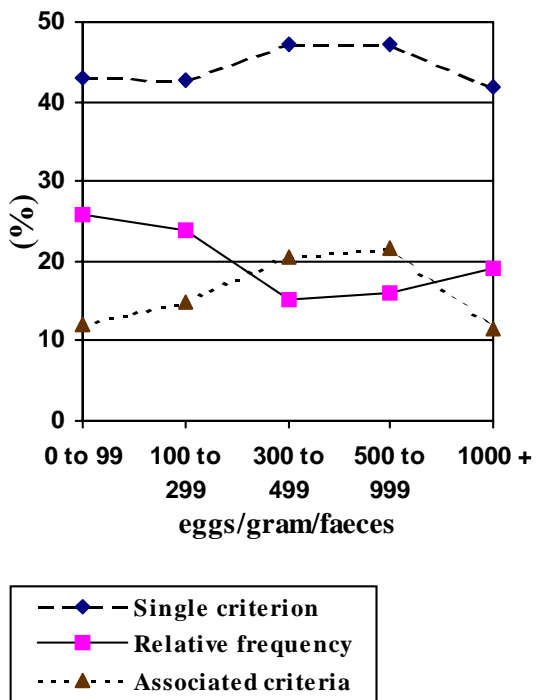

Fig. 1: distribution of relative frequency and anaemia prevalence according to intensity infection with Ancylostomidae. Matriz da Luz, PE, Brazil.
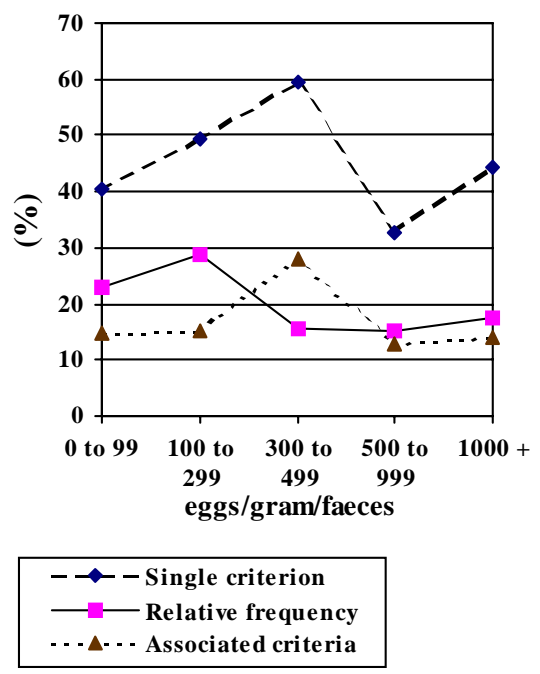

Fig. 2: distribution of relative frequency and anaemia prevalence according to intensity infection with Trichuris trichiura. Matriz da Luz, PE, Brazil.

children under 6 years old treated in Recife outpatient health services (Salzano et al. 1985, Monteiro \& Szarfarc 1987). Romani et al. (1991) detected a progressive reduction of anaemia with age. They also observed that the mean haemoglobin values are influenced by age.

Reviews on feeding and nutrition in Brazil stress the fact that very few papers present data on anaemia lower than $10 \%$. The great majority of them shows prevalences around $20 \%$ and some higher than 40\% (Batista Filho \& Barbosa 1985).
Similar data have also been described for other developing countries. In a county of Panama 22.3\% of children aged 6 to 12 had levels of haemoglobin lower than the normal, independent of sex and age (Robertson et al. 1992). In Havana 38.8\% of children (both sexes) under 2 years had haemoglobin below $11 \mathrm{~g} / \mathrm{dl}$ (Vidal et al. 1985). In Tanzania a high prevalence of anaemia was reported in rural populations over 15 years old and it was suggested that this might become a public health problem having an impact on the economy of that country (Kitange et al. 1993).

We did not detect any statistically significant association between parasite intensity, as measured by epg, and anaemia (Table II) even when we analyzed associations for those parasites commonly related to anaemia such as Ancylostomidae (Fig. 1) and T. trichiura (Fig. 2) despite high levels of prevalence for these worms in the sample studied. It's known, however, that egg counts are highly variable and may not be a good tool for the assesment of worm burden (Anderson \& Schad 1985).

A significant relationship between anaemia and T. trichiura was detected in Panama, in a group that presented more than 5,000 eggs/gram/faeces and among those that were at the same time infected by Ancylostomidae and T. trichiura (Robertson et al. 1992). The loss of blood resulting from infections of 1,000 adult T. trichiura parasitism is about $5 \mathrm{ml} /$ day, which is a very heavy pathogenic parasite burden (Roche \& Layrisse 1966, Bundy \& Cooper 1989).

In another study, carried out in Papua Guinea, in spite of the detection of a negative correlation between hookworm infection and plasma ferritin no correlation was seen between parasite burden and levels of hemoglobin (Pritchard et al. 1991). Some authors suggest that the absence of correlation between parasite burden and hemoglobin level or haematocrit might be explained by the low intensity of infection and they conclude that this correlation may occur only when the number of eggs is higher than 5,000/gram/ faeces. The appearance and persistence of anaemia, probably occurs only when the loss of blood is induced by a great number of worms (Crompton et al. 1993).

In this study only four children had more than 5,000 Ancylostomidae eggs/gram/faeces and eight children had more than 5,000 T. trichiura eggs/ gram/faeces.

Our results may probably be related to the low burden of parasites in the sample. They also show that the treatment of intestinal helminths and of anaemia must be followed by haematological examinations, so that any other inducing cause of anaemia can be evaluated and properly treated. 


\section{ACKNOWLEDGEMENTS}

To Dr Felipe Gonçalves for the children entry forms, to Drs Carmelita Maia and Cynthia Braga for medical assistance.

\section{REFERENCES}

Anderson RM, Schad GA 1985. Hookworm burdens and faecal egg counts: an analysis of the biological basis of variation. Trans $R$ Soc Trop Med Hyg 79: 812825 .

Arruda IKG, Arruda BKG 1994. Nutrição e desenvolvimento. Cad Saú Púb 10: 392-397.

Arruda IKG, Nacul LC, Batista Filho M 1991. Anemia em gestantes atendidas no pré-natal do IMIP. II Papel da instrução, enteroparasitoses e peso gravídico (1). Rev IMIP 5: 3-6.

Barbosa CS, Silva CB 1992. Epidemiologia da esquistossomose mansônica no Engenho Bela Rosa, município de São Lourenço da Mata, Pernambuco, Brasil. Cad Saú Púb 8: 83-87.

Batista Filho M, Barbosa NP 1985. Pró-Memória. Alimentação e Nutrição no Brasil: 1974-1984. Brasília Editora e Gráfica Canadá, 87 pp.

Bundy DAP 1985. Worms in aetiology of iron deficiency-anaemia in the Caribbean region. Cajanus 18: 197-215.

Bundy DAP, Cooper S 1989. Trichuris and trichuriasis. Hum Adv Parasitol 28: 107-173.

Chan M-S 1997. The global burden of intestinal nematode infections - fifty years on. Parasitol Today 13: 438-443.

Cook JD, Skikne BS, Bayners RD 1994. Iron deficiency: the global perspective. Adv Exp Med Biol 356: 219-228.

Crompton DWT, Whitehead RR 1993. Hoohworm infections and human iron metabolism. Parasitology 107: S137-S145.

Dean AG, Dean JA, Burton AH, Dicker RC 1990. Epi Info, Version 5.01: a Word - Processing Database and Statistics Program for Public Health on IBM Compatible Microcomputers, Center for Diseases Control, Atlanta, 384 pp.

Desai NV, Choudhry P 1993. Nutrition anaemia in protein energy malnutrition. Indian Ped 30: 1471-1483.

FIBGE - Fundação Instituto Brasileiro de Geografia e Estatística 1991. Censo Demográfico, Resultados Preliminares p. 56-57, FIBGE, Rio de Janeiro.

Kitange HM, Swai ABM, Kilima PM, Masuki G, Alberti KGMM, MacLarty DG 1993. Anaemia is a major public health problem in Tanzania. Health Policy Plan 8: 413-424.

Monteiro CA, Szarfarc SC 1987. Estudo das condições de saúde das crianças do município de São Paulo, SP (Brasil), 1984 - 1985 - V - Anemia. Rev Saúde Pública 21: 255-260.

Oliveira I 1990. Anemia por deficiência de ferro, p. 543548. In F Figueira, OS Ferreira, JGB Alves (eds), Pediatria, MEDSI, Rio de Janeiro.

OMS - Organizacion Mundial de La Salud 1972. Anemias Nutricionales: Informe de un Grupo de Expertos en Nutrición de la OMS. Geneva, Technical Reports
Series, $503 \mathrm{pp}$.

PAHO - Pan American Health Organization, WHO World Health Organization 1994. Nutritional situation in the Americas. Epidemiol Bull 15: 1-6.

Pritchard DI, Quinnell RJ, Moustafa M, Slater AFG, Raiko A, Dale DDS, Keymer AE 1991. Hookworm (Necator americanus) infection and storage iron depletion. Trans R Soc Trop Med Hyg 85: 235-238.

Rapaport SI 1990. Introdução à Hematologia, Roca, São Paulo, 450 pp.

Rey L 1991. Parasitologia, 2nd ed., Guanabara Koogan, Rio de Janeiro, $731 \mathrm{pp}$.

Robertson LJ, Crompton DWT, Sanjur D, Nesheim MC 1992. Trichuris trichiura and the growth of primary schoolchildren in Panama. Trans $R$ Soc Trop Med Hyg 86: 654-656.

Roche M, Layrisse M 1966 The nature and causes of "Hookworm Anemia". Am J Trop Med Hyg 15: 10291102.

Romani SAM, Lira PIC, Batista Filho M, Siqueira LAS, Freitas CLC 1991. Anemias em pré-escolares: diagnósticos, tratamento e avaliação, Recife, PE, Brasil. Arch Latinoamer Nutr Guatemala 41: 159167.

Salzano AC, Batista Filho M, Flores H, Calado CL de A 1980. Prevalência de anemia no ciclo gestacional em dois estados do nordeste Brasileiro, Pernambuco e Paraíba. Ver Bras Pesq Méd Biol 13: 211-214.

Salzano AC, Torres MAA, Batista Filho M, Romani SAM 1985. Anemias em crianças de dois serviços de saúde de Recife, PE (Brasil). Rev Saúde Pública 19: 499-507.

Sigulem DM, Tudisco ES, Goldberg P, Athaide MMM, Vaisman E 1978. Anemia ferropriva em crianças no município de São Paulo. Rev Saúde Pública 12: 168178.

Simmons WK 1985. Anaemia in the Caribbean: its prevalence and causes. Cajanus 18: 217-236.

Szarfarc SC 1985. Diagnóstico da deficiência de ferro na infância. Rev Saúde Pública 19: 278-284.

Torres MAA, Sato K, Queiroz SS 1994. Anemia em crianças menores de dois anos atendidas nas unidades básicas de saúde no Estado de São Paulo, Brasil. Rev Saúde Pública 28: 290-294.

Turconi SJ, Turconi VL 1992. Anemia ferropriva: incidência numa população infantil. Pediatria Moderna 28: 107-112.

Unicef - Fundo das Nações Unidas 1994a. Helmintíases Intestinais. A Prescrição 6: 1-8.

Unicef - Fundo das Nações Unidas 1994b. Anemia. A Prescrição 11: 1-16.

Vidal H, Du Puente R, Defaix HG 1985. Deficiencia nutricional de hierro en niños de 6 meses a 2 años. Rev Cuba Pediatr 57: 384-391.

Vital - Vitamin A Fiedls Support Project 1993. Tercer Taller Regional Deficiencias de Vitamina A y Otros Micronutrientes en America Latina y el Caribe. Arlington, IN-14.

Vyas D, Chandra RK 1984. Functional implications of iron deficiency, p. 45-60. In A Stekel, Iron Nutritional in Infancy and Childhood, Reven Press, New York. 
